Hannah Lucas
University of Oxford

\title{
PRIVATE PILGRIMAGES AT SYON ABBEY? A NOTE ON CAMBRIDGE UNIVERSITY LIBRAY MS FF.6.33
}

In the central folios (70v-1r) of Cambridge, University Library, Ff.6.33, is a reddish-brown discolouration, rectangular in size, which seems to have bled through the material, faded but still visible on one bifolium. The mark resists immediate classification as a spillage or other such accidental damage and thus raises the question of how we might interpret such markings. Has the manuscript been used to store an item flat? Is it a mark left by a historical binding? Or is it 'reader's residue', perhaps an imprint of a bookmark or an item directly related to the contents of the collection of texts, which combines to form a matrix of reading apparatus? I am interested in this last possibility and, given the information available about the manuscript regarding its provenance, ordinatio, and scribe, think it a worthy thought experiment to consider how a particular item - possibly a pilgrim badge - might have augmented the use of the manuscript for its intended reader.

Cambridge University Library, Ff.6.33 (henceforth F) is a collection of devotional texts, written in the late fifteenth or early sixteenth century. The materials within include texts such as The boke of the XII patriarkys, indulgences of Pope John XII, an exposition on the Pater Noster, the Latin Ave Maria followed by an English translation, the Treatise on the Nine Virtues, a translation of the Rule of St. Augustine, the Ladder of Foure Ronges (a translation of the Scala Claustralium), and most significantly for our inquiry, The Rewyll of Seynt Sauioure, the Middle English Rule of St. Bridget of Sweden. The manuscript is small (176 x $130 \mathrm{~mm}$ ), unembellished and in good condition, with blue and red ink used for simply elaborated initials and paraph markers. There are neither signs of marginalia nor illuminations, rendering $\mathrm{F}$ a simple and compact devotional tool. 
A. I. Doyle has identified the single hand as that of scribe William Darker (d. 1512/3), a Carthusian monk of Sheen Charterhouse in Middlesex. ${ }^{1}$ The script is a neat Anglicana Formata that has ben described by Doyle and Malcolm Parkes as 'fere-Textura', or 'a skillful amalgam of elements from various kinds of handwriting'. ${ }^{2}$ Localised to Middlesex by the Linguistic Atlas of Late Mediaeval English, Darker's dialect supports the contextual and palaeographical evidence that F was written locally for Sheen Charterhouse and Syon Abbey. In terms of the manuscript's use and audience, the inclusion of the Rule of St. Saviour (St. Bridget's Rule) supports Doyle's suggestion that F was written for the nuns at Syon. Indeed, James Hogg goes so far as to say that 'it is virtually certain that $[\mathrm{F}]$ originated from the nuns' library at Syon'. ${ }^{3}$ Supporting Hogg's claim is the presence of Darker's hand in other manuscripts written for the Syon sisters, such as Glasgow University Library, Hunterian MS T.6.18, which, dated c. 1501-2, was written for the fifth abbess of Syon, Elizabeth Gibbs. The manuscript's linguistic design also confirms this view. The fact that every Latin word in F is glossed supports ownership by the nuns rather than the brothers. After all, it is wellestablished that the sisters commanded some level of vernacular literacy, as evidenced by the liturgical Myroure of oure Ladye, in which the author addresses the Syon sisters and claims justification for its use of English: 'Forasmoche as many of you, though ye can synge and rede, yet ye can not se what the meanynge therof ys' ${ }^{4}$

As well as a thriving textual community, Syon Abbey was a renowned pilgrimage site for many —among its pilgrims included, for instance, Margery Kempe, who visited Lammastide in 1434. In 1425, the Pope granted pilgrims to Syon the so-called Vincula indulgence, and later, the 'Pardon of Syon', which was granted to pilgrims visiting Syon at certain annual times. By visiting specific shrines, pilgrims would earn these indulgences and could, by papal decree, lessen their purgatorial sentence. As Alexandra Da Costa notes, such pilgrimage indulgences, 'combined with the faculty of blessing rosaries granted to the brethren in 1500 by Pope Alexander VI', made Syon 'an important religious destination'. ${ }^{5}$ Souvenirs passed 
hands to and from, as pilgrims both purchased and deposited items. In addition to high numbers of items left at Bridget's shrine, Brian Spencer describes the often 'crudely made' pilgrim badges issued to pilgrims at Syon, ${ }^{6}$ and $\mathrm{Da}$ Costa comments that printed copies of devotional books also may have been available for purchase at Syon as souvenirs for literate pilgrims. ${ }^{7}$ One example, recovered from the Thames, offers a potential model for pilgrim badges issued at Syon. It presents a traditional depiction of Bridget, with decorative protrusions from the main scene of the lead/tin alloy design, and 'SCA BRIGT' inscribed on the frame. ${ }^{8}$

The later printed works produced at Syon usually include a similar visual representation of St. Bridget. ${ }^{9}$ Such contextual evidence of pilgrimage souvenirs begins to suggest that the mark in F may be residue from an image - perhaps a pilgrim badge itself — used practically either as a bookmark or as a spiritual tool. The majority of extant pilgrim badges are made of a pewter or lead/tin alloy, with gold, silver, and silver-gilt used more rarely. Consequently, many badges leave telltale marks outlining their presence, ${ }^{10}$ to which the mark of the object in question within $\mathrm{F}$ bears parallels. The red-rust colouring suggests possibly an organic material, or indeed the presence of iron oxide, which could possibly indicate impurities in the metal alloy. Since the metal would have been slightly thicker than the membrane, it is plausible that it was stored between the central folios so as not to disturb the binding. Further analysis would be required, of course, to determine with any certainty the material in question.

Such a badge may have originated from Syon, or indeed it may have been brought from another site, such as the Bridgettine mother house in Vadstena, Sweden: there was contact in both directions between Syon and Vadstena, and a badge may therefore have been brought from Sweden by a member of Syon, or even left by a Swedish visitor, since there were Swedish nuns and brothers in England for many years. ${ }^{11}$ The specific regulations of Syon Abbey may support such a claim. While the Syon sisters themselves were strictly enclosed, the meditative programme at Syon fostered a sense of readerly individuality. As Christopher 
De Hamel remarks, while 'the nuns were allowed no personal possessions whatsoever $[\ldots]$ surely the rules were flexible enough to permit the keeping of a prayer-book on indefinite loan for private use in the cell or cloister'. ${ }^{12}$ The extant texts containing names or initials support this, and token images can even be found within Syon books. For example, Sister Joan Sewell's copy of The Scale of Perfection is annotated with tau crosses, which were believed to have apotropaic qualities.

The inclusion of pilgrim badges as 'devotional ephemera' within manuscripts has been investigated by relatively recent scholarly attention. Preliminary investigations were led by Kurt Köster, ${ }^{13}$ who laid the groundwork for subsequent research, such as that conducted by Hanneke van Asperen and Kathryn Rudy. ${ }^{14}$ The practice of actually sewing badges into private prayer books became prevalent by the second half of the fifteenth century, largely concentrated in the southern Netherlands and northern France. This popular form of visual devotion led to a tradition of illuminated trompe l'oeil representations of badges in manuscript margins. A noteworthy example appears, for instance, in folio 240r of The Hours of Catherine of Cleves (New York, Pierpont Morgan Library, MS 917). Rudy has pointed out that not all badges are 'pilgrims' badges', suggesting that many round badges that bear images of the Lamb of God, the Crucifixion, the Resurrection, and other sacramental themes, were souvenirs of having taken the Eucharist. ${ }^{15}$ Other instances of readerly individualization of manuscripts also include, for example, the use of scallop shells as border decoration around Suffrage prayers to St. James, in reference to the pilgrimage to Santiago de Compostela. ${ }^{16}$

Even if used by a later reader or owner of the manuscript rather than directly by a Syon sister herself, the potential merging of the two objects — the book and the pilgrim badge-would have extended the reading experience into a haptic and extra-visual dimension. Considering the scarcity of illuminations within F, the addition of a physical image may have served to heighten the reader's sensory experience of devotion. It may have evoked some of what Sarah Stanbury calls the 'pleasures of holding and of having, ${ }^{17}$ of which iconoclasts of the period 
were wary, should worship be directed to the sign instead of the signified. ${ }^{18}$ Avoiding such misplaced devotion requires a reading praxis; a form of lectio divina directed by the ordinatio of the manuscript itself. Lacking an original table of contents or any extensive marginal apparatus, the ordinatio of $\mathrm{F}$ suggests that distinct tabulae might have been redundant to the intended reader, most likely because they would have already been well-acquainted with the texts. The mansucript is, Laura Saetveit Miles has argued, 'a fluid inspirational catalyst for meditation,' one in which 'intimate knowledge of the volume functioned as the reader's mental tabulae'. ${ }^{19}$

Extant badges often depicted an element of the pilgrim's destination or a saintly attribute. For instance, the image of Bridget writing her Revelations in the aforementioned Syon Abbey badge. In this context, then, the badge would have become a miniaturized encryption of the saint. Charged with the saint's signified attributes, the iconic image operates as a trigger or catalyst for devotional readings that require recall of a retained narrative. The compact size of the book, coupled with the badge, would form a portable matrix of devotional apparatuses perfectly suited to pilgrimage travel. However, and perhaps most significantly, the charged iconography of the badge could also offer the reader (whether a lay gentryperson or enclosed religious) the chance to recall the absent, signified narrative of the saint, offering him or her the opportunity for a mental or proxy pilgrimage. It is certainly an alluring possibility to consider a reader making a 'pilgrimage through the pages' to St. Bridget's revelations. Such a reading opens a realm of possibilities for understanding the significance of devotional artifacts in late medieval reading practices generally, as well as illuminating the possibility of unconventional private reading practices in the strictly-enclosed community of Syon.

\footnotetext{
${ }^{1}$ A. I. Doyle, 'William Darker: The Work of an English Carthusian Scribe', in Medieval Manuscripts and their Makers (Turnhout, 2011), 200.

${ }^{2}$ Malcolm Parkes, English Cursive Book Hands (Oxford, 1969), 8.
} 
${ }^{3}$ James Hogg, The Rewyll of Seynt Sauioure and A Ladder of Foure Ronges by the Which Men Mowe Clyme to Heven (Salzburg, 2003), ix.

${ }^{4}$ John Henry Blunt, ed., The Myroure of oure Ladye, Containing A Devotional Treatise on Divine Service, 1530 A.D, EETS OS 19 (London, 1873), 2-3.

${ }^{5}$ Alexandra Da Costa, Reforming Printing: Syon Abbey's Defence of Orthodoxy 1525-1534 (Oxford, 2012), 47.

${ }^{6}$ Brian Spencer, Pilgrim Souvenirs and Secular Badges, Medieval Finds from Excavations in London (London, 1998), 46.

${ }^{7}$ Da Costa, Reforming Printing, 47.

${ }^{8}$ Lars Andersson, Pilgrimsmärken Och Vallfart: Medeltida Pilgrimskultur i Skandinavien (Stockholm,1989), 112; Spencer, Pilgrim Souvenirs and Secular Badges, 81.

${ }^{9}$ See Da Costa, Reforming Printing, 50.

${ }^{10}$ Megan H. Foster, 'Pilgrimage Through the Pages: Pilgrim's Badges in Late Medieval Devotional Manuscripts', PhD diss. (University of Illinois at Ubana-Champaign, 2011), 1349.

${ }^{11}$ Thanks to Vincent Gillespie for this suggestion (personal correspondence 18/07/18).

${ }^{12}$ Christopher De Hamel, Syon Abbey: The Library of the Bridgettine Nuns and Their Peregrinations After the Reformation (London, 1991), 74.

${ }_{13}$ Kurt Köster, 'Religiöse Medaillen und Wallfahrts-Devotionalien in der Flämischen Buchmalerei des 15. und Fruhen 16 Jahrhunderts', in Buch and Welt (Wiesbaden, 1965), 45950. Also Köster, 'Kollektionen Metallener Wallfahrts-Devotionalien und Kleiner Andachtsbilder, Eingenäht in Spätmittelalterliche Gebetbuch-Handschriften' in Das Buch und Sein Haus: Erlesenes aus der Welt des Buches, ed. B. Haller (Wiesbaden, 1979), 87-95; Köster, 'Gemalte Kollektionen von Pilgerzeichen und Religiösen Medaillen in Flämischen Gebet- und Stundenbüchern des 15. und Frühen 16. Jahrhunderts' in Liber Amicorum Herman Liebaers (Brussels: 1984), 485-535.

${ }_{14}$ Asperen, Hanneke van, Pelgrimstekens op Perkament: Originele en Nageschilderde Bedevaartssouvenirs in Religieuze Boeken (ca 1450-ca 1530), PhD diss. (Radboud Universiteit Nijmegen, 2009); Kathryn Rudy, Piety in Pieces: How Medieval Readers Customized their Manuscripts (Cambridge, 2016); Rudy, 'A Pilgrim's Book of Hours: Stockholm Royal Library A233', Studies in Iconography 22 (2001), 237-77 and 'Addendum', Studies in Iconography 22 (2001), 163-4; Rudy, 'Sewing the Body of Christ: Eucharist Wafer Souvenirs Stitched into Fifteenth-Century Manuscripts, Primarily in the Netherlands', Journal of Historians of Netherlandish Art (2016), unpaginated.

${ }^{15}$ Rudy, Piety in Pieces, 171, note 35.

${ }^{16}$ Anne-Margreet As-Vijvers, 'More Than Marginal Meaning? The Interpretation of GhentBruges Border Decoration', Oud Holland, cxvi.i (2001), 3-33.

${ }^{17}$ Sarah Stanbury, The Visual Object of Desire in Late Medieval England (Philadelphia, 2008), 45.

${ }^{18}$ Margaret Aston, Lollards and Reformers. Images and Literacy in late Medieval Religion (London, 1984), 141.

${ }^{19}$ Laura Saetveit Miles, The Rewyll of Seynt Sauioure: The Middle English Translation of St. Bridget's Regula Salvatoris: An Edition, MPhil diss. University of Cambridge (2005), 60. 